\title{
Esoterogeni og aktiv forskjellsdannelse: Religion og identitetsskapning, i Stillehavet og andre steder
}

Thorgeir Kolshus Seksjon for mangfoldsstudier Institutt for internasjonale studier og tolkeutdanning OsloMet - Storbyuniversitetet thoko@oslomet.no

Keywords:

Esoterogeny identity politics social differentiation denominationalism Vanuatu 
Abstract

Esoterogeny and the creation of difference: Religion and identity making, in the Pacific and elsewhere

Taking its cue from Marx' and Weber's grand theorizing, a key narrative in Western modernity has been the inevitable dissolution of pre-modern identities. This thesis has informed both policy making and notions of global agency, and in effect caused a particular worldview in which everyone will become more or less the same - what I refer to as the Star Trek-vision of globalized culture and values. In this article, I borrow the linguistic concept of 'esoterogeny', the creation of the obscure, to address whether difference, far from being coincidental, serves a more fundamental experiential purpose and consequently is actively maintained. The empirical point of departure are church fissions and denominational dynamics in the Pacific island state of Vanuatu. I argue that in an age characterized by identity politics, in which recognition and attention are scarce resources, all keen observers of social systems should expect the outcome of ever more global interaction to lead to an increase in articulations of social and cultural difference. 


\section{Introduksjon: Forskjellenes region ${ }^{\mathrm{i}}$}

Faget sosialantropologi presenteres gjerne som «det sammenlignende studium av samfunn og kulturer». Ved å studere beslektede fenomener og institusjoner i ulike samfunn, kan vi antropologer få frem både systematiske forskjeller og likheter i for eksempel politisk organisering, slektskap og kjønnsroller, samt samspillet mellom disse. At vår art, som deler alle biologiske forutsetninger, kan ha så mange ulike tilnærminger til verden og vår plass $\mathrm{i}$ den, er det som har fascinert antropologer siden fagets spede begynnelse for drøye 150 år siden. Antropologiens ambisjon om å gripe det fellesmenneskelige innebærer altså en tilsynelatende paradoksal vektlegging av alt som skiller oss fra hverandre. Dette er dels faghistorisk begrunnet. Flertallet av de tidligste sentrale bidragsyterne var nemlig overbevist om at kulturforskjeller ville forsvinne ettersom kolonisering av både politisk og økonomisk art trengte seg stadig lengre inn i selv de mest perifere områder (Boas, 1966; Rivers, 1914; Malinowski, 1922). Derfor var det noe nær et kall å beskrive så mye som mulig av variasjonen som fortsatt fantes, før «sivilisasjonen» uvegerlig ville ha valset over alle vesentlige forskjeller og omskapt verdens kulturelle mangfold til et mer eller mindre enhetlig landskap.

Stillehavsregionen Melanesia, som består av dagens Ny-Guinea, Salomonøyene, Vanuatu og Fiji, har helt fra starten vært gjenstand for uforholdsmessig stor antropologisk oppmerksomhet, ettersom den sosiokulturelle variasjonen her var like påfallende som den var fascinerende. På en $\varnothing y$ med bare noen tusen mennesker kunne man finne radikalt forskjellige språk og skikker over korte avstander. For den tidligere antropologien utgjorde dette noe i nærheten av et naturlig laboratorium, der prinsippene for samfunns og kulturers utvikling kunne studeres og teoretiseres. Den underliggende antagelsen var at utviklingen var en konsekvens av relativ isolasjon. For hva skulle ellers bakgrunnen for denne babelske forvirringen være? \& kunne forstå hverandre måtte da være uendelig mye mer hensiktsmessig?

Drøye hundre år etter at disse første omfattende etnografiske studiene ble gjort, er forståelsen av at relativ isolasjon er en forutsetning for at kulturforskjeller skal vedvare ettertrykkelig tilbakevist - for dette var på ingen måte samfunn som var isolert og ikke «visste bedre». Denne artikkelen baserer seg på empiri fra en av de åtte bebodde øyene i Banksgruppen nord i den melanesiske øystaten Vanuatu. Her bor det rundt ti tusen mennesker, som holder seg med ganske ulike kulturelle systemer og femten forskjellige språk, i tillegg til nasjonalspråkene bislama, fransk og engelsk. For lingvister og antropologer er det interessant å forstå hvordan forskjellene har oppstått, men også hvordan de vedvarer - til tross for hyppig kontakt, med handel, giftemål, midlertidige opphold etc. på tvers av språk og kulturer. Med så små språkgrupper er det nærliggende à tenke at et gjensidig forståelig kommunikasjonssystem ville vært mer funksjonelt, og at et slikt derfor ville ha tvunget seg frem på bekostning av språklig diversitet - det lingvisten William Thurston kaller 'eksoterogeni', «the process of simplifying an esoteric language to create a register that is more easily acquired by outsiders» (1987: 150). Men historisk-lingvistisk forskning i øygruppen (se f.eks. François, 2013) peker like gjerne på den motsatte tendensen, nemlig det Thurston kaller 'esoterogeni', «a process that adds structural complexity to a language and makes it more efficient as a medium of communication among people of the same group, while making it more difficult for outsiders to learn to speak well» (1987: 150; se også Bradshaw, 1995).

Det later med andre ord til at verdien av ikke å bli forstått av andre overstyrer fordelen ved å kunne bli forstått av dem. Språk er altså ikke bare et kommunikasjonsmedium, men også en viktig markør for samhørighet innad gjennom grensedragning utad. I denne artikkelen vil jeg argumentere for at dette ikke bare gjelder språkutvikling i Stillehavet, men kan overføres også til andre aspekter ved vår menneskelige tilværelse. Begrepet esoterogeni vil med andre ord bli løftet ut av stillehavslingvistikken og brukt som betegnelse på et langt mer utbredt fenomen: vår hang til forskjellsskapning. 


\section{Kirkesplittelse og konsolidering}

I Matt Tomlinson og Debra McDougalls artikkelsamling med antropologiske perspektiver på forbindelsene mellom politikk og kristendom i Stillehavet (2013), har flere av bidragsyterne latt seg inspirere av den toneangivende amerikanske teologen og etikeren $\mathrm{H}$. Richard Niebuhrs første større arbeid, The social sources of denominationalism (1929). Her beskriver han dynamikken mellom etablerte kirker og «sekter» som bryter ut av disse. Niebuhr viser at bruddene som oftest har sitt opphav i utbryternes frustrasjon over en stivnet form for organisasjon og tilbedelse, som ifølge de frustrerte har ført til at inndelingen i menigheter ofte følger andre sosiale skillelinjer, som for eksempel klasse og etnisitet, og dermed opphever kristendommens radikale budskap om de troendes enhet. Utbryterne er med andre ord motivert av et ønske om å revitalisere kirken, og det gjøres best gjennom revolusjon snarere enn reform. Reform blir likefullt konsekvensen, av to grunner: Bruddet vil vekke de etablerte kirkene til en motreaksjon; mens de nye formene for kristendom i løpet av en generasjon blir institusjonalisert og 'denominasjonalisert', med mange av de samme kjennetegnene som opprinnelig førte til kirkesplittelsen (se Bialecki, 2014; Haynes, 2017: 154-157). Lettere tabloid sagt: De er gått fra 'sjokk' til 'skikk' - og på veien er de også i de aller fleste tilfeller blitt forbundet med en distinkt gruppe eller sosialt sjikt og er dermed ikke kommet nærmere målet om å realisere kristen enhet.

Niebuhr gjør det mesterstykke å kombinere et normativt siktemål med en analyse som viser at dette siktemålet vanskelig lar seg realisere. Han anser utvilsomt kirkesplittelse og økt konfesjonelt mangfold som et høyst beklagelig hinder for økumenisk samarbeid og en større kristen enhet, men faller likevel ikke for fristelsen til å underkommunisere at all empiri tilsier at denne utviklingen vil fortsette. Nyere etnografiske studier av kristendom i ulike deler av verden bekrefter at de sosiale mekanismene han peker på, i høyeste grad er gyldige (se for eksempel Bialecki $(2014,2017)$ fra USA, Haynes (2017) fra Zambia og Eriksen (2012) fra Vanuatu). I denne artikkelen vil jeg spinne videre på Niebuhrs analyse av de sosiale konsekvensene av dogmatisk friksjon. Etter et bredt historisk sveip over toneangivende samfunnsviteres holdning til forskjellige aspekter ved relasjonen mellom religion, modernitet og identitetsdannelse, vil jeg argumentere for at det historisk-lingvistiske begrepet 'esoterogeni' har mye for seg også i en samfunnsvitenskapelig forstand, som et redskap for å belyse prosesser knyttet til gruppedannelse og bevisst annerledesgjøring og markering av sosialt relevante skillelinjer. Dette danner bakteppe for analysen av materiale fra mange års etnografisk forskningsengasjement på øya Mota nord i Vanuatu i den sørvestlige delen av Stillehavet, der samspillet mellom den 150 år gamle lokale anglikanske kirken og den relativt nylig etablerte Assemblies of God viser hvordan konfesjonell endring først og fremst finner sted basert på det Mikhail Bakhtin kaller «skjult polemikk» eller «intern polemisk diskurs», definert som «word with a sideward glance as someone else's hostile word» (1984: 196, se også 205-210) og derfor har en brodd mot et kirkesamfunns signifikante Andre. Slik blir konfesjonelle forskjeller forstørret til også å markere, artikulere og utgjøre basis for nye sosiale skillelinjer.

\section{En kort fortelling om religion og sosial identitet}

At religion ikke kun er et spørsmål om individuell tro men også om sosial identitet, er en påstand de færreste vil finne problematisk nå til dags. Likevel møtes dette fenomenet ofte med en grunntone av forbløffelse, ettersom mange stadig ser ut à la seg overraske av at omfavnelsen av religiøse identiteter og ny-konservative tolkninger av religiøse på- og forbud griper om seg. Forståelsen av moderniteten som en ensrettet utvikling fra mytisk til rasjonell tenkning, har vært en ledende fortelling blant premissgivere for spesielt norsk og svensk offentlighet, noe Terje Tvedt (2017) og Kajsa Norman (2018) nylig har påpekt.ii At nye generasjoner som «burde vite bedre enn sine foreldre» like gjerne kunne være tilbakeskuende 
(les: religiøst motiverte og interesserte) som de er fremtidsomfavnende, later nærmest til a være ubegripelig for medlemmer av skravleklassen.

Opphavet til denne seiglivede verdensanskuelsen finner vi hos to av sosiologiens tre opphavspersoner. For både Karl Marx og Max Weber er forestillingen om modernitetens uavvendelig fremmarsj nærmest et aksiom: Moderne rasjonalitet var det som til syvende og sist ville medføre avmystifisering av verden, avkledning av mytiske tankesett, oppløsningen av førmoderne identiteter og fremveksten av et politisk og administrativt lederskap basert på egenskaper snarere enn opphav. Og selv om Weber var langt mer opptatt av religion som kulturelt fenomen enn Marx var, iii og også har en mer elegisk klangbunn i beskrivelsen av avmystifiseringen, er premissen like fullt at forestillinger uten vitenskapelig belegg vil forsvinne som dugg for modernitetens vårsol (se Asad, 2003 for en grundig kritikk). Hos den tredje av sosiologiens stamfedre var imidlertid forståelsen en annen. Emile Durkheims blikk for religion bunnet riktignok i et ønske om å forklare hvordan sosiale fellesskap opprettholdes over tid snarere enn interesse for fenomenet i seg selv, men denne interessen førte til dyptloddende $s ø \mathrm{k}$ i etnografisk og historisk litteratur etter hva som kunne være kimen til religiøs tenkning og rituell praksis (Durkheim, 1995). iv Durkheim var ikke helt fri for det kulturevolusjonistiske tankesett som hadde vært rådende $\mathrm{i}$ samfunnsvitenskapen de siste tiårene av 1800-tallet, og i sin jakt etter den enkleste form for religiøs tankegang fulgte han sine forgjengere og rettet derfor søkelyset mot australsk totemisme. ${ }^{\vee}$ Men der hans kolleger brukte høyst tvilsomme historiske data og svært mangelfulle etnografiske beskrivelser som ble tilpasset spekulative teorier om sivilisasjoners fremvekst, var Durkheim først og fremst opptatt av å forklare religion som samfunnsfaktor. Og ved å rette oppmerksomheten mot totemisme og klanssystemer, bidro han sterkt til à vise nettopp forbindelsen mellom trossystemer og sosiale identiteter. Forskjeller mellom slektsgrupper ble av folk selv forklart med referanse til forskjeller i deres mytiske verden. Det sosiale og det religiøse stod med andre ord i et gjensidig forsterkende forhold til hverandre: Den mytiske verden bød på et vokabular for samfunnsorganisering, samtidig som den i stor grad gjenspeilet den samme organiseringen.

\section{Forskjellsskaping}

Durkheims totemismeanalyser var en viktig inspirasjon for Claude Lévi-Strauss (1964). Men der Durkheim var opptatt av å forklare totemisme som sosialt fenomen, ble den i Lévi-Strauss' strukturalistiske innpakning uttrykk for noe langt mer grunnleggende, nemlig hvordan menneskers hjerne er oppbygget. På samme måte som språket består av enkeltlyder som ikke blir meningsbærende før de opererer i kontrast med andre lyder, er også all kunnskapstilegnelse basert på kontraster (Lévi-Strauss, 2002). $\AA$ si at noe er 'kaldt', innebærer en implisitt referanse til noe 'mindre-kaldt' og dermed varmt i sammenligning. For Lévi-Strauss var totemisme nok et eksempel på menneskets tilbøyelighet til à skape et overskudd av mening gjennom å klassifisere for klassifiseringens skyld: Vi er rett og slett en skapning som ynder å skape orden gjennom å systematisere forskjeller. Denne innsikten gjenfinnes i Fredrik Barths svært innflytelsesrike bidrag til forståelse av etnisitet som fenomen (1969). Hans revolusjonerende grep var å vende oppmerksomheten vekk fra hva som kjennetegnet en etnisk gruppe til fordel for grensene mellom slike grupper. På det viset styrte man unna essensialiserende og ahistoriske fremstillinger av nærmest tidløse iboende trekk og fikk heller frem hvordan forskjeller ble uttrykt og endret seg over tid. Religion var ett blant mange fenomener - språk, slektskapsideologi, mat, klær, utseende, kunst, opphavsmyter, etc, etc - som inngikk i repertoaret for à skape, vedlikeholde og kommunisere etnisk tilhørighet. Alt kunne brukes for å skape «en forskjell som gjør en forskjell», slik Gregory Batesons berømte definisjon av informasjon lyder (1972). Barths innsikt muliggjorde teoriutvikling som var mer maktorientert enn hans egen var. I kjølvannet av avkolonisering og hevingen av det europeiske jernteppet ble identitetspolitikk, dvs. aktiv «røkting» av forskjeller, et sentralt studiefelt for samfunnsvitere. De mange etniske konfliktene mellom 
folk som tidligere hadde levd tett sammenvevd i fred og fordragelighet, gav opphav til studier av de små forskjellers tyranni - oppsummert i Stanley Tambiahs lekkert formulerte paradoks, «The time of becoming the same is also the time of claiming to be different» (1989: 348). Samtidig bød et stadig voksende turistmarked og fremveksten av nasjonale og internasjonale urfolksrettigheter på muligheter for å omgjøre synlige forskjeller til klingende mynt tydeliggjort i Jean og John Comaroffs Ethnicity, Inc. (2009), der de argumenterer for at 'identitetsøkonomi' er en naturlig følge av identitetspolitikk.

Med andre ord: Forestillingen om at med modernitetens fremvekst vil alle før-moderne identiteter forvitre, har vist seg ikke å tåle møtet med virkeligheten. Etnisitet og andre prosesser som skaper eller opprettholder sosiale skillelinjer er altså i høyeste grad et moderne fenomen. Og i kjølvannet av en stadig tettere økonomisk og delvis også kulturell integrering av mennesker og samfunn i et globalt fellesskap, kan det virke som om disse forskjellene blir stadig viktigere for oss. Kort sagt: Kontakt med andre gjør oss ikke nødvendigvis likere, men like gjerne at vi blir mer klar over forskjellene som eksisterer - og muligens også mer opptatt av å vedlikeholde disse forskjellene. Det er for å tjene som merkelapp på slike prosesser jeg ønsker å utvide det analytiske bruksområdet for esoterogeni-begrepet. Som eksempel på dets anvendbarhet, vil jeg bruke det for å forstå prosesser knyttet til religiøs identitetskapning på en liten øy i Stillehavet.

\section{Esoterogeni og kommunisering av annerledeshet}

Da jeg i 1996 for første gang ankom Vanuatu for å utføre etnografisk feltarbeidvi på øya Mota helt nord i øystaten, tilbragte jeg et par netter i et lite gjestehus i hovedstaden Port Vila. Jeg var klar over at missiologen Charles Forman for nærmere førti år siden beskrev Stillehavet som «the most solidly Christian part of the world» (1982: 227), og var derfor ikke altfor overrasket over at det tilgjengelige lesestoffet bestod av bibelfortellinger og religiøse pamfletter. Etter å ha bladd gjennom en håndfull eksemplarer av den siste kategorien, var jeg slått av hvor lite variasjon det var i budskapet. Det aller meste hadde dreiet seg om feiringen av Sabbaten og hvilken villfarelse søndagsgudstjenesten var, rikt bestrødd med sitater fra både GT og enkelte fra NT, der spesielt Lukas 16:17 var hyppig gjengitt: «Før skal himmel og jord forgå, før en eneste prikk i loven faller bort.» Jeg var vant til at evangeliserende brosjyrer fremstilte det mest sentrale i det kristne budskapet, med hovedvekt på syndsforlatelse og frelse til evig liv gjennom Jesu' død og oppstandelse. $\AA$ bruke så mye plass på dagen for feiring av gudstjenesten fremstod derfor som et snodig valg. Det skulle gå pinlig lang tid før jeg endelig innså at min vert måtte ha vært syvendedagsadventist. Seventh-day Adventists (som i Melanesia kun omtales med akronymet SDA) er ingen mastodont i global målestokk, men har fătt stor utbredelse de hundre årene kirken har vært tilstede i Melanesia. Dens vektlegging av Bibelens eskatologiske budskap og søken etter endetidstegn gjorde at den skilte seg ut fra metodister, katolikker, lutheranere, presbyterianere og anglikanere, som opprinnelig bedrev misjon i området fra midten av 1800tallet. For mange melanesierne fortonet ikke SDAs endetidsmotiver seg nevneverdig forskjellig fra deres før-kristne verdensbilder. Det som imidlertid var fremmed, var spisetabuene fra 3. Mosebok. De fleste melanesiere bor i nærheten av hav, med blant annet skalldyr, snegler og ål, eller elver, med kreps. Den klart mest omseggripende endringen var imidlertid erklæringen av grisen som uren. I Melanesia har svin til alle tider vært noe langt mer enn bare en kilde til sårt tiltrengt dyreprotein (Rappaport, 1977; Jolly, 1994; Rio, 2007; Eriksen, 2008). Den har først og fremst vært det eneste allment aksepterte betalingsmiddel, som kan byttes inn i koner, hemmelig kunnskap eller sosial status. En fet hermafrodittgris med støttenner i dobbelt sirkel gjør stort inntrykk på nær samtlige melanesiere. Som en tilpasning til stillehavslivet insisterte SDA-misjonærer dessuten på at man måtte holde seg unna kava, en mildt berusende drikk laget av roten på planten piper methysticum, som er et vanlig element i mange rituelle sammenhenger, i tillegg til å være en viktig bestanddel $\mathrm{i}$ menns sosiale liv. 
Generasjonene av samfunnsvitere som fulgte Marx og Weber var ikke bedre til å spå enn de var. Og nettopp denne radikale omleggingen av livsførsel som SDA-misjonærene insisterte på, gjorde at de færreste stillehavsforskere kunne forestille seg at nettopp denne kirken skulle få en slik gjennomslagskraft. Der spesielt anglikanerevii og katolikker var opptatt av å bevare mest mulig av kulturelt særpreg for å skape levedyktige lokale menigheter, stod SDA for det diametralt motsatte. Ved å be sine medlemmer fornekte mye av det de tidligere hadde satt høyt, sa man samtidig at andre ting var langt viktigere. På det fenomenologiske plan er det nok lettere for den enkelte troende å ta inn over seg at Dommens dag og Det nye Jerusalem er rett rundt hjørnet når også det jordiske liv fortoner seg radikalt annerledes. På et samfunnsplan, som er det jeg ønsker å belyse, fungerer dette budskapet først og fremst som en sosial avgrensning - mellom de gammel-troende, med sin feiring av søndagen og verdsetting av tradisjoner, og de ny-troende, som feiret Sabbaten og fulgte strenge mattabuer i påvente av Kristi snarlige tilbakekomst. Uten kavadrikking og svinespising blir det vanskelig å ha sosial omgang med venner, slekt og naboer som tilhører andre trossamfunn. Dessuten velger en del SDA-medlemmer demonstrativt å arbeide på søndager, gjerne i påsyn av søndagsgudstjenestegjengerne. Slik fungerer SDAs særegne på- og forbud som markører av identitet, som blir samholdsskapende innad og avstandsskapende utad. viii Og det var i lys av dette brosjyrene jeg kom over disse første dagene i Vanuatu måtte leses. I stedet for direkte å kalle alle andre villfarne, fremheves i stedet de trekkene ved SDAs lære som gjør at de skiller seg ut - slik som feiring av gudstjeneste på lørdag fremfor søndag og betydningen av å følge spisetabuene i 3. Mosebok. Ved hjelp av slik «skjult polemikk» eller «intern polemisk diskurs» (Bakhtin, 1984: 59, 205-210), foretar man en dogmatisk grenseoppgang uten å være eksplisitt på at det er det man ønsker å gjøre.

\section{Et antropologisk og anglikansk pilegrimssted}

$\varnothing y a$ Mota er en stor, liten $\varnothing y$, både i antropologiens faghistorie og i misjonshistorien. De to henger nøye sammen, ettersom den mest begavede av alle misjonærantropologer, Robert Henry Codrington (1830-1922), viet mye av sin nærmere tredve år lange tilværelse i Stillehavet fra 1864 til studier av denne lille øyas språk, kultur og skikker - noe som blant annet medførte at fenomenet mana, som på motaspråket konnoterer 'kraft' eller 'virkning' og brukes som forklaring på hendelser som overgår det forventede (Kolshus, 2013, 2016a), ble sentralt i all komparativ religionsforskning. ${ }^{i x}$ Motas plass i misjonshistorien ble sikret gjennom at språket ble brukt som lingua franca ved de hundrevis av anglikanske skoler som ble etablert i Melanesia og at også Bibelen og The Book of Common Prayer ble oversatt til motesisk og brukt i alle kirkelige sammenhenger i det samme området; flertallet av melanesiske misjonærer de første tre tiårene av Melanesian Missions virke kom fra Mota, og det gjorde også den første melanesiske prest, George Sarawia, som på eget initiativ opprettet den kristne 'mønsterlandsbyen' Kohimarama, der de nyomvendte skulle leve etter de første kristnes eksempel; og den legendariske første biskop av Melanesia, John Coleridge Patteson, som led martyrdøden i 1871 (Kolshus og Hovdhaugen, 2010), tilbragte årlig opp til flere måneder på øya. Det er vanlig blant anglikanere i Melanesia å henvise til Mota som «Kirkens vugge», og dette har gitt den lille øya på rundt ti kvadratkilometer og med knapt tusen innbyggere en posisjon og kulturell innflytelse som langt overgikk det størrelsen skulle tilsi (Kolshus, 2013).

Da jeg i 1996 kom til øya for mitt første etnografiske feltarbeid, var det også Motas plass i den anglikanske misjonshistorien folk trakk frem. Stadig dukket det opp historier om at menigheter på fjerne øyer foretrakk motesisk liturgi og skriftlesninger fremfor å bruke for lengst oversatte versjoner på egne språk. ${ }^{\times}$De var også stolte over at ingen andre kirkesamfunn hadde etablert seg på Mota, i motsetning til hva tilfelle var ellers i Vanuatu, der konverteringer og kirkesplittelse var svært vanlig (Eriksen, 2009). På naboøya Mota Lava med under to tusen innbyggere fantes det for eksempel over ti forskjellige kristne trossamfunn. Riktignok var ikke gudstjenesteiveren alltid like påtagelig blant de yngre. Men med nærmere 
ett hundre helgendager, to ukers pålagt påskefeiring og tre ukers julefeiring i tillegg til søndager, ville de aller fleste likevel ha deltatt på godt over hundre gudstjenester i løpet av et år. Og med daglige morgen- og/eller kveldsbønner i hver eneste landsbykirke, var kirkelige aktiviteter klar premissgiver for det meste annet. Det var kun en mann, Samson, som aldri var å se i kirken. Han var kjent som en arbeidsom kar som gjerne gikk sine egne veier. Overfor meg bedyret han at han trodde minst like mye som de andre og at hans manglende kirkegang kun var et utslag av egen særhet, «ō nunumya namuk gap», og understreket at han støttet opp om alle aktiviteter som fant sted utenfor kirkerommet. 135 år etter at den først slo rot på Mota, stod den anglo-katolske utgaven av anglikanisme fjellstøtt på sitt melanesiske arnested. ${ }^{x i}$

\section{En kulturrevolusjon}

Da jeg vendte tilbake for et nytt feltarbeid i 2002, var stemningen en annen. Diskusjoner om kirkens tilstand fant sted langt hyppigere nå enn hva tilfelle var fem år tidligere, og uttrykket 'ministry', i betydningen 'kirkerøkt', var blitt del av dagligtalen. Det var også påfallende mye klaging over manglende punktlighet. $\AA$ møte presis, selv uten kronometer, hadde vært viktig for tidligere generasjoners anglikanere, men var ikke tatt altfor alvorlig under mitt første feltarbeid. Nå var det igjen vektlagt av alle seriøse voksne og ikke kun et tilbakevendende ankepunkt for kirkeledere. Den anglikanske kirkens kvinneorganisasjon, Ira Veve, var også langt mer aktiv enn før, og det var opprettet en egen gruppe for ungdom, Ira Yut, (for alle ugifte mellom 12 og 40), som hadde hyppige møter og minst en gang i måneden feiret langvarige midnattsgudstjenester, med ny liturgi, gitarakkompagnert lovsang og vitnesbyrd fra forsamlingen. Tidligere hadde det vært nærmest uhørt åpent å kritisere presten, til tross for at slik kritikk i en del tilfeller utvilsomt var på sin plass. Men nå var det en rekke som offentlig uttrykte sin misnøye med Mama Malakai, som slettes ikke var verre enn de to som hadde tjent Mota under mitt første feltarbeid. Uroen som omgav kirken var med andre ord merkbar, og mine forsøk på å få svar på hva som hadde endret seg, falt stort sett på stengrunn. Det var først etter en visitt til landsbyen Garamal, som ligger avsides til på den sørvestlige delen av øya, at jeg forstod hva som hadde hendt. Jeg hadde reagert på at Garamal var utelatt fra den roterende gudstjenestesyklusen. Da jeg endelig tok en tur innom, ble jeg møtt av en landsby som siden sist hadde vokst voldsomt $\mathrm{i}$ folketall. Mens den i 1996-97 hadde vært den minste med knappe førti sjeler, var den nå blitt den største med over 130 innbyggere. Jeg ble tatt minst like godt imot der som ellers, og da jeg ble introdusert for deres pastor, Walter Woser fra Mota Lava, innså jeg endelig at her hadde noe radikalt nytt funnet sted. De fortalte smilende at de for et par àr siden hadde funnet seg en ny ' $/ \bar{g} g / u e^{\prime}$, trosretning, og at de nå tilhørte AOG (Assemblies of God), en pinsekirke med global utbredelse.

I tiden som fulgte besøkte jeg Garamal så ofte jeg kunne og brukte mye tid på å få oversikt over hendelsesforløpet, både gjennom samvær og i samtaler med enkeltmedlemmer eller hele grupper. Jeg opplevde dem som bemerkelsesverdig åpne om både tvil og dilemmaer, selv under den første samtalen, som fant sted under måltidet etter en gudstjeneste og inkluderte nær samtlige voksne i landsbyen. Der kom det frem at den umiddelbare bakgrunnen for konverteringen hadde vært en langvarig krangel over bruksrett til jord. En av de involverte var førstediakon i den anglikanske kirken. På ett punkt var han blitt så lei av krangel og ufred at han bestemte seg for å flytte - og da han forlot landsbyen, tok han med seg gaver han og andre hadde gitt til utsmykning av alteret og kirkebygget forøvrig. Denne skjendingen av kirkerommet ble dråpen som fikk begeret til å flyte over for Andrew, Garamals folkevalgte høvding, og han gav seg i vei til provinshovedstaden Sola på naboøya Vanua Lava, på jakt etter en ny kirketilhørighet. Han var beundringsverdig ærlig på at han ikke visste hva han lette etter. Det eneste kriteriet var at kirken skulle være ikke-anglikansk. I Sola traff han sekretæren for den lokale domstolen, som også var leder for AOG-menigheten der. Hun gav ham noen poser med brukttøy og løfter om at noen fra deres australske vennemenighet ville 
komme og hjelpe dem å reise et nytt kirkebygg. Andrew dro hjem og snart opplevde AOG på Mota en eksplosiv vekst, ettersom mange andre hushold som hadde vært involvert i konflikter med den samme stridbare diakonen også flyttet til dem og byttet kirketilhørighet i samme slengen. Da jeg spurte dem om hva som var den største forskjellen mellom deres nye og gamle tro, trakk de frem fraværet av mellommenn til Gud. Som anglikanere hadde de vært avhengige av prestene for å få Herrens velsignelser, mens nå var de i direkte kontakt med Ham. Blant annet kunne de be om regn, noe de hadde fătt i overflod - i motsetning til hva tilfelle var for resten av øya, som i 2002-03 led under kraftig tørke som følge av værfenomenet El Niño. Deres pastor var mer av en rådgiver og følgesvenn enn en person med makt over deres liv, sa de. Jeg visste at en rekke av konvertittene ifølge de flestes oppfattelse hadde opplevd at prester hadde brukt sin eksklusive kontakt med Gud til å påføre dem eller deres familie lidelse og endog død (Kolshus, 2013, 2016a). Men de var svært tilbakeholdne med å kritisere anglikanske geistlige direkte. I stedet fremhevet de pastor Walters mange dyder, som en gavmild mann som sjelden ble sint og forøvrig gikk foran som et godt eksempel. Blant annet hadde han minnet dem på betydningen av punktlighet. Da dette ble nevnt, viste mange frem armbåndsurene sine, som ellers var et sjeldent syn på øya. Walter sa at han ønsket å være et godt eksempel også for de andre på Mota, så hver gang han ble invitert til markeringer av sekulære høytider som representant for AOG, dukket han opp på slaget. På Mota brukes tidspunktet det inviteres til for å markere hvor betydningsfull anledningen er. Står det på programmet at det skal begynne kl 16, er det en mindre viktig feiring enn de som er oppført å begynne $\mathrm{kl} 12$. Alle vet at et arrangement aldri vil starte før nærmere solnedgang likevel, så klokkeslettene bidrar kun til å skille mellom store og små anledninger. Dette visste selvfølgelig pastor Walter, men han møtte opp likefullt og satt på landsbyens samlingsplass i alles beskjemmede påsyn. Den ventende Walter ble et moralskestetisk uttrykk for at AOG mestret punktlighet, som er en av få dyder de og den anglikanske majoriteten hadde til felles. At de færreste ankom den anglikanske messen før lenge etter kl. 0730, hadde stadig vært kommentert og kritisert, uten at det førte til forbedring. I motesernes øyne var dette et symptom på mer enn kun makelighet. $\AA$ komme presis refereres til som å følge 'hvitmannstid', og det rådet en allmenn oppfatning blant både religiøse og verdslige ledere at på øyene ellers i Vanuatu var de mye flinkere til dette. Derfor hadde de også tilgang til mange av godene som fulgte i kjølvannet av 'divelopmen', et mangslungent begrep som henviser til ulike aspekter av økonomisk utvikling og modernisering (Kolshus, 2017). Så lenge Mota var henfallen til det de kaller 'svartmannstid', ville øya aldri komme seg opp og frem. Og det var åpenbart at de forklarte Motas gammelmodighet og mangel på utvikling med en mentalitet som ble forvaltet og formidlet av den anglikanske kirken, uten at de sa dette direkte.

AOGs nye tilnærming til tid hadde flere andre sider. Blant annet var deres arbeidsdag strengt organisert. Den varte fra kl 08 til kl 1530, og alt arbeid ble utført i fellesskap. De hadde en femdagers arbeidsuke, der faste dager var avsatt til henholdsvis kvinne- og ungdomsformål, mens de tre gjenværende ble viet enkelthushold. Med alle landsbyens voksne som disponibel arbeidskraft var det liten tvil om at de fikk utført langt mer enn hvert hushold klarte på egen hånd. Og ettersom man kunne sette strek over de rundt ett hundre helgendagene som den anglokatolske majoriteten fortsatt feiret, xii ble mange uker årlig frigjort til vanlig arbeid. AOGmedlemmene hadde da også fătt mer tid til å lage og selge kopra, som er den eneste inntektskilden for alle bortsett fra en håndfull lærere og anglikanske geistlige. De hadde derfor mer penger mellom hendene, som var nok en indikator på at livet som fulgte i kjølvannet av deres nye tro var nærmere knyttet til divelopmen enn anglikanernes og at Herren kanskje hadde dem kjærere.

Av forskjeller som direkte angikk deres rituelle praksis, vektla de at en AOG-gudstjeneste mer bar preg av å være et fellesskap der alle hadde en rolle å spille og alt kunne skje. De nevnte spesielt det faktum at kvinnene hadde en langt mer sentral plass hos dem. Margaret, en eldre kvinne og god venn fra første feltarbeid, fortalte at selv om hun hadde gått til anglikanske gudstjenester hele sitt liv, var det lite hun egentlig forstod av hvorfor ting ble 
gjort som de ble gjort eller hva som foregikk - og verre var det, sa hun, at det ikke virket som om dette hadde bekymret prestene. Nå, derimot, følte hun at hennes deltagelse gjorde en forskjell, og hun la til, litt brydd og litt stolt, «wa lōkenake ō lölömaran me kalō galean», 'og nå er jeg blitt litt smartere' (jf. Haynes, 2017: 63). De understreket også at spontaniteten i deres gudstjenestefeiring gjorde at de følte hvordan Den hellige ånd var tilstede. Nok en gang fikk jeg en klar fornemmelse av at dette retorisk fungerte som Bakhtins interne polemiske diskurs (1984), med en implisitt kontrast til de anglikanske høymessene: Ved ̊̊ fremheve Åndens utvilsomme tilstedeværelse hos dem, stilte de implisitt spørsmål ved hvorvidt det samme var tilfelle hos deres anglikanske slektninger og venner. Jeg bet meg også merke i at AOG-medlemmene brukte det engelske uttrykket 'Holy Spirit' i stedet for det motesiske 'Ō Vui we Rōño', som virket å være en understrekning av AOGs internasjonale aner og dermed også en ytterligere distansering fra deres anglikanske fortid. I forlengelsen av Margarets vitnesbyrd, påpekte hennes mann Joel at fraværet av dogmatiske gnisninger hadde vært et hinder for intellektuell vekst og dermed også for divelopmen. Som eneste øy med kun ett kirkesamfunn hadde Mota selv valgt å bli hengende etter, mente han. Den ensrettetheten det anglikanske flertallet hadde sett på med stolthet, så han på som en hemsko. Og han ventet store endringer nå som det var to.

\section{Den enes dyder er den andres laster}

Da jeg spurte dem mer inngående om hvordan de opplevde kontakten med den anglikanske majoriteten, var de raske med å understreke at de jo alle hadde den samme Gud, men at enkelte anglikanere oppførte seg som om det ikke var tilfelle. De syntes for eksempel det var underlig at de ble nektet å holde offentlige forbønnsgudstjenester for Mota eller besøke syke slektninger for å helbrede dem. Anglikanerne mener kanskje øya vår er velsignet nok som det er, var det en som foreslo, kun halvt i spøk. De lot være å si direkte at den anglikanske ledelsen var engstelig for at folk skulle se at Gud kunne påkalles direkte uten presten som mellommann, men det lå nok en gang en skjult polemikk mot anglikanernes hierarkiavhengighet i det de trakk frem.

Deres uttalte opplevelse av åndelig myndiggjøring som fulgte bruddet med de anglikanske geistliges monopol på direkte kontakt med Gud og tilgang til hans mana, var for meg den mest slående forskjellen mellom Garamal-folket og den anglikanske majoriteten. Men denne individualiseringen av gudsrelasjonen var nettopp det anglikanere, leg som lærd, trakk frem som det største ankepunktet mot AOG. Reynold, som i åtte år hadde vært medlem av den anglikanske monastiske ordenen The Melanesian Brotherhood og hadde bedrevet misjonsvirksomhet på andre øyer i Melanesia, var skamfull over at de hadde fors $\varnothing$ kt å holde Garamals konvertering skjult for meg, for dette var jo ingenting å være flau over. De var jo deres familie og venner! Reynolds bror Nixon var blitt AOG-medlem, etter å ha giftet seg med landsbyleder Andrews datter. Reynold og hans kone Hamilton understreket at folket i Garamal var hardtarbeidende og fikk utført mye med sin nye arbeidsorganisering. Da vi kom inn på forskjellene i ritualer, ble de imidlertid mer kritiske. «Det er bare en klappekirke», ō lōglue tape wōsawōsa gap, sa Hamilton, med henvisning til det hun mente var en gudstjenesteorden som bestod av sang, skriftlesning, sang, skriftlesning, preken, sang og avsluttende bønn. Noen dager senere gjentok Mama Malakai karakteristikken av AOG som en klappekirke, og la til at de også var helt uten sakramenter, før han rettet på seg selv og sa at de jo hadde sakramenter, «bare ingen ordentlige». Han la ikke skjul på sin sorg over Garamals skifte av trosretning, først og fremst fordi «slikt virket splittende på folket», 'vlewōara ō sul'. Ifølge ham var Mota hverken stor nok eller folkerik nok til at to forskjellige trossamfunn kunne leve fredelig sammen. Da jeg spurte ham om deres konfesjonsgrunnlag, ble han usikker og endte opp med à gjenta merkelappen 'klappekirke'. Han fortalte med nostalgisk vemod om sine første år i kirkens tjeneste tredve år tidligere, da han begynte som novise i The Melanesian Brotherhood. Den gang hadde det vært knapt en håndfull forskjellige kirkesamfunn i Vanuatu, og med mulig unntak for SDA hadde disse stort sett respektert grensene seg imellom. Men 
nå for tiden dukket nye kirker opp nærmest som paddehatter (Eriksen 2009). At det nå også hadde nådd Mota, anglikanernes vugge i Melanesia, var et tegn i tiden. Vel vitende om at mange kritiserte hans embetsutøvelse, sukket han og innrømmet at de pastorale utfordringene var større enn noensinne.

Ungdomsarbeidet for Ira Yut, med nattlige lovsangsgudstjenester og andre karismatiske trekk, var utvilsomt et svar på spenningen ved AOGs nye tilbedelsesformer. Kvinnearbeidet gjennom Ira Veve var en gammel organisasjon som ble revitalisert, også dette sannsynligvis som en reaksjon på AOG-kvinnenes sentrale plass både i gudstjenester og i landsbylivet forøvrig. Ellers hadde AOGs tilstedeværelse den virkning på majoriteten at de omfavnet nettopp de elementene som skilte seg mest ut fra Garamals nye tro. Den anglikanske «motreformasjonen» bar med andre tydelig preg av de kjennetegn Bakhtin oppgir for en intern polemisk diskurs, med en implisitt men likefullt tydelig avstandtagen til sentrale AOGdyder. Sammenlignet med 1997 bød de anglikanske høymessene på mer av det mystiske og sanselige: Før lesning av evangelieteksten ble Bibelen båret rundt i kirken omsluttet av en sky av røkelse og tilbake til en bukkende prest; det var flere liturgiske ledd som presten fremførte så lavt at det tilsynelatende var snakk om en direkte transaksjon mellom ham og Gud; under innstiftelsesordene for nattverden var kunstpausene i forbindelse med transformasjonen blitt enda lengre enn de hadde vært; og under vigslingen av dåpsvannet førte presten utstudert sakte fingeren ned i det, holdt den der med dramaturgisk stillhet i det som fremstod som en liten evighet, før han endelig trakk den like sakte ut (Kolshus, 2016a). Anglikanernes svar på AOGs frigjøring fra presten rolle som mellommann var med andre ord å bekrefte prestens mellommannsmonopol og dermed deres fullstendige avhengighet av ham. Og der AOG-folket fremhevet at nå forstod de hva som foregikk i gudstjenestene og at mystisk hokuspokus ikke var påkrevd for at Ånden skulle være blant dem, var den anglikanske høymessen mer utbrodert, i lengde og i opplevelsesspekter, enn på lenge. I tillegg fikk jeg det klare inntrykk at tegn på bot og underkastelse, uttrykt gjennom langvarig kneling på hardpakket gulv, bøyde rygger og nakker og hyppige gjentagelser av korsets tegn, var langt mer vanlig blant gudstjenestegjengerne - i klar kontrast til AOGs foretrukne positur, oppreist med hevede hender og ansiktet mot himmelen. Kort sagt: anglikanerne møtte utfordringen fra AOG med å omfavne det de visste var AOGs ankepunkter mot dem. Slik fikk de kommunisert at Garamals kirke var en klappekirke uten hverken historisk dybde eller teologisk tyngde. Og slik ble den enes kirkes dyder den andre kirkes laster.

\section{Ni år etter: konsolidering og harmonisering}

I 2012 var jeg tilbake på Mota for et kort femukers feltopphold, blant annet for å se nærmere på hvordan relasjonen mellom anglikanere og AOG hadde utviklet seg. Det første som slo meg var en ny anglikansk selvsikkerhet, som i stor grad var forårsaket av at en avdeling av The Melanesian Brotherhood hadde flyttet til Mota. De seks munkene og deres kapellan var direkte underlagt biskopen, og ettersom biskopen, pga. den anglokatolske vektleggingen av den apostoliske suksesjon, anses som den ultimate kilde for mana, var den anglikanske kirken på Mota bokstavelig talt mektigere enn tidligere. AOGs ekspansjon hadde også løpt ut i sanden. En del hadde endog vendt tilbake til moderkirken, slik at det i Garamal nå var ca. 80 innbyggere. Dette inkluderte en familie som etter en lengre krangel hadde meldt overgang til Families in Christ, en frittstående karismatisk kirke som ifølge dem var oppstått på øya Espiritu Santo, to hundre kilometer sør for Mota. De hadde bygget et hus på sitt område som deres pastor skulle bo i når han en gang kom på besøk. Det hadde imidlertid gått noen år siden de forlot AOG og de ventet fortsatt på visitt, så i mellomtiden var de flittige besøkende ved anglikanske messer og deltok gjerne ved festligheter i forbindelse med helgendager (jf. Haynes, 2017: 59-60). For Sissirei, mannen i familien, var dette helt naturlig: «Văr Far i himmelen er jo en og den samme». Roger og hans familie hadde også forlatt AOG, men deres valg av SDA hadde vært mer problematisk. I begynnelsen insisterte de på å arbeide på søndager, slik deres mer konfronterende trosfrender på naboøyene gjorde. Men da de 
anglikanske lederne bad dem om å la dette være, lot de sosiale hensyn veie tyngre enn dogmatisk konflikt og nå levde de i fred og fordragelighet med sine anglikanske naboer. Etter det jeg kunne se, virket de heller ikke synderlig opptatt av å følge diettforskriftene i 3 . Mosebok.

Under AOG-gudstjenesten jeg deltok ved, fikk jeg klart inntrykk av at luften hadde gått ut av ballongen. Gudstjenesten fant sted i deres fantastisk flotte skolebygg, som de innrømmet nesten å ha jobbet seg i hjel for å reise, og ble ledet av en nyankommet pastor fra Mota Lava og hans kone fra Epi lengre sør, som skulle ha ansvar for barnearbeidet. Jeg hadde ankommet til vanlig gudstjenestetid kl. 09, men det var kun fire kvinner til stede og ennå ingen menn til tross for at barna og pastorparet hadde varmet opp med lovsang i nærmere en halvtime. Selv om gudstjenesten fant sted rett ved landsbyen, skulle det gå over en time før sistemann gjorde sin entre, og ennå var det en rekke familier som glimret med sine fravær. Jeg tok meg selv i å føle medlidenhet med det hardtarbeidende pastorparet, som gjorde alt de kunne for å skape en stemning av inderlig åndelighet uten at menigheten viste særlig tegn til å speile deres engasjement. Svaret var enda mer følelsesladede utbrudd og oppfordringer til å tilbe Gud med hevede armer, «hvis man følte for det», som pastoren skyndte seg å legge til - men den eneste som fulgte oppfordringen var en eldre kvinne, og da kun med en hånd hodehøyt til værs og den andre plassert bak ryggen. Kontrasten mellom gudstjenestelederne og forsamlingen forøvrig var slående, og på vei til måltidet etter gudstjenesten lekte jeg med tanker om at dette var et sted Anden hadde forlatt.

Så feil kan man ta. Riktignok var det en ganske annen stemning i Garamal nå enn den lettere eksalterte som hadde rådet ni år tidligere. Men i samtalene jeg hadde med AOG-medlemmene den dagen og i ukene som fulgte ble jeg stadig slătt av hvor mye tryggere de virket å være, både på egen tro og på deres liv forøvrig. De var klare på at tungetalen og alle besettelsene som hadde preget gudstjenestene deres de første par årene nå var sjeldne foreteelser. Den gang hadde de sett det som tegn på at Den hellige ånd var tilstede. Nå, derimot, gav Ånden seg til kjenne som en hvisken til hver og en. For meg var det spesielt interessant at de brukte ordet motaordet mana om Guds kraft, noe de tidligere hadde unngått, og i tillegg snakket de nå om 'Vui we rōño' i stedet for 'Holy spirit' (Kolshus, 2016a). Relasjonen til den anglikanske ledelsen var også mye bedre, og de deltok på hverandres feiringer og rituelle markeringer. Og da jeg spurte dem om også de benyttet seg av miraklene som munkene i The Melanesian Brotherhood utførte ved hjelp av sin mana fra biskopen, bekreftet de dette. Munkene var anglikanere, men de hjalp alle som bad om det. I tillegg hadde mennene i Garamal igjen begynt å være med når de hemmelige Tamate-kultenes danser ble oppført, noe som krevde flere ukers samvær for å lage hodeplaggene og øve inn trinnene. Det var med andre ord blitt mange flere møteplasser, både slike der deres bekjennelsesforskjeller var tydelige men også av ikke-religiøs art. Slik ble alle motesere minnet på at de levde overlappende liv, der kanskje ikke forskjellene i trosbekjennelse likevel skulle veie tyngre enn alt det andre som forenet dem - blant annet det faktum at på en liten øy med tusen mennesker, står alle $\mathrm{i}$ et slektskapsforhold til hverandre.

\section{Noen korte slutninger}

Den første fasen etter Garamals konvertering til AOG var kjennetegnet av aktiv forskjellsskapning, en prosess jeg i denne artikkelen kaller esoterogeni. Esoterogeni er en sosial sentrifugalkraft, som polariserer og sementerer forskjeller, slik at den enes partens dyder fremstilles som lastefulle av den andre. Eksoterogeni, derimot, kan brukes som betegnelse på tiden etter konsolideringsfasen, slik jeg møtte den i 2012. Eksoterogeni har preg av en sentripetalvirkning, der det som skiller noen ad nedtones til fordel for likhetene. Den bredere økumeniske tilnærmingen, som både anglikanere og AOG og også de to husholdsstore menighetene Families in Christ og SDA stod for, er ikke nødvendigvis et tegn på at alle ulikheter vil forvitre: Eksoterogeni henviser først og fremst til en prosess der sosiale og kulturelle forskjeller underkommuniseres. AOG-medlemmenes og anglikanernes holdning 
kan kanskje forstås som en utvikling fra sjokk til skikk, der AOG er blitt en moden menighet som ikke har samme behov for å skape indre samhold basert på identitetsmarkører de vet vil virke støtende og vekke motvilje hos sine «signifikante andre». Samtidig er dette reduserte behovet for å vise sin egen fortreffelighet et uttrykk for at AOG har konsolidert sin posisjon, slik at de sosiale skillelinjene mellom AOG og den anglikanske majoriteten er i ferd med å sementeres. Dette vil i så fall være i tråd med Niebuhrs tese om hvordan grupper som bryter med en organisert kirke ut fra et ønske om en mer radikal kristen enhet, gradvis institusjonaliseres og ender opp som noe som tilsvarer det som forårsaket bruddet. Denne «denominasjonaliseringen» (Niebuhr 1929; Bialecki, 2014) blir med andre ord markør for nye, permanente sosiale skillelinjer.

Parallellen jeg har trukket i denne artikkel, mellom gruppedannelser som er basert på dogmatisk friksjon og gruppedannelser basert på etnisitet, vil kanskje virke søkt for noen selv om det på ingen måte var uvanlig blant de tidlige kirkefedrene å henvise til kristendommens tilhengere som en ethnos (Bialecki, 2017: 24; Nongbri, 2013), der konnotasjonene 'folk' og 'hedninger' begge understreker deres status som forskjellige fra omgivelsene. Og det er mange årsaker til den eksplosive veksten som pinse- og karismatiske kirker nå opplever på verdensbasis (se Hefner, 2013; Robbins, 2007; Haynes, 2017; Kolshus, 2016b). Men at interreligiøs dynamikk utvilsomt foregår $i$ et samspill med andre sosiale differensieringsmekanismer, bør være åpenbart for enhver som følger med på nyhetsbildet. At dogmatiske forskjeller kan gå fra uvesentligheter til å bli etniske grensemarkører på til dels svært kort tid, har blant andre Tone Bringas forskning fra Bosnia vist med tankevekkende tydelighet $(1995,2005)$. I likhet med de tidligste antropologene, finner jeg at slike dynamikker av og til er enklere å få oversikt over på et lite sted som Mota. Jeg vil hevde at utviklingen i relasjonen mellom anglikanere og AOG-medlemmer som jeg har beskrevet over, bærer i seg noe mer grunnleggende: som nok et eksempel på at forskjeller har en verdi og derfor også har en strategisk komponent som overstyrer praktiske hensyn, blant andre fordelene ved å kunne gjøre seg forstått og fordelene ved å dele målsetninger og livsprosjekt. Det er dette aspektet jeg hevder er overførbart til analysen av forskjellsdannende prosesser også i andre sosiokulturelle sammenhenger. Når vi tar de identitetsøkonomiske forholdene Comaroff og Comaroff (2009) påpeker med i betraktningen, påskyndet av en tidsånd der oppmerksomhet og anerkjennelse er en knapp ressurs, er det lite grunn til å tro annet enn at den aktive forvaltningen av annerledeshet vi i dag gir merkelappen 'identitetspolitikk' vil gripe om seg. Marx og Webers tese om fornuftens ufortrødne fremmarsj har vist seg å være like nærsynt som den er feilslått. Star Trek-visjonen, der vi må utenfor fra vårt eget solsystem for å finne noen som er forskjellige fra oss, vil fortsette å være ren science fiction. Situasjonen i dagens Europa i skrivende stund, med Brexit nært forestående og sterk vind i seilene for etnonasjonalistiske og identitære bevegelser, forteller sitt om at forskjellsopprettholdelse stikker dypere enn praktiske hensyn. Esoterogeni er et nyttig begrep for å avmystifisere dette fenomenet og utfordre politiske og andre samfunnsprioriteringer som har som forutsetning at alle til slutt vil bli like. 


\section{Litteratur}

Argyrou, V. (2003). 'Reflexive modernization' and other mythical realities. Anthropological Theory 3 (1), 27-42.

https://doi.org/10.1177/1463499603003001750

Asad, T. (2003). Formations of the Secular: Christianity, Islam, Modernity. Stanford, CA: Stanford University Press.

Bakhtin, M. (1984). Problems of Dostoevsky's poetics. Minneapolis: University of Minnesota Press. https://doi.org/10.5749/j.ctt22727z1

Barth, F. (1969). Introduction. I F. Barth (red) Ethnic groups and boundaries (s. 9-38). Oslo og Bergen: Universitetsforlaget.

Bateson, G. (1972). Steps to an ecology of mind. Chicago og London: University of Chicago Press.

Bialecki, J. (2014). After the denominozoic: evolution, differentiation, denominationalism. Current Anthropology 55 (S10), 193-204. https://doi.org/10.1086/678284

Boas, F. (1966). Kwakiutl ethnography. Chicago: University of Chicago Press.

Bradshaw, J. (1995). How and why do people change their languages? Oceanic Linguistics 34 (1), 191-201. https://doi.org/10.2307/3623118

Bringa, T. (1995). Being Muslim the Bosnian Way: Identity and Community in a Central Bosnian Village. Princeton, NJ: Princeton University Press.

Bringa, T. (2005). Returning Home: Reconstruction and Reconciliation in Post-War BosniaHerzegovina. I S. Gloppen, E. Skaar og A. Suhrke (red) Roads to Reconciliation (s. 187201). Lanham: Lexington Books.

Codrington, R. H. (1891). The Melanesians. Oxford: Clarendon.

Comaroff, J. L. og J. Comaroff (2009). Ethnicity, Inc. Chicago: University of Chicago Press. https://doi.org/10.7208/chicago/9780226114736.001.0001

Durkheim, E. (1995). The elementary forms of religious life. New York: The Free Press.

Durrad, W. (1912). Banks Islands report. Southern Cross Log (Australia/New Zealand edition) $17,337-343$.

Eriksen, A. (2008). Gender, Christianity and change in Vanuatu. Aldershot: Ashgate.

Eriksen, A. (2009). Healing the nation: In search of unity through the Holy Spirit in Vanuatu». Social Analysis 53, 67-81. https://doi.org/10.3167/sa.2009.530105

Fabian, J. (1983). Time and the Other. New York: Columbia University Press.

François, A. (2013). Shadows of bygone lives. The histories of spiritual worlds in northern Vanuatu. I R. Mailhammer (red) Lexical and structural etymology (s. 185-245). Boston og Berlin: De Gruyter.

Forman, C. (1982). The island Churches of the South Pacific: Emergence in the twentieth century. Maryknoll, NY: Orbis Books.

Frazer, J. (1996). The golden bough. New York: Touchstone.

Haynes, N. (2017). Moving by the spirit. Berkeley, CA: University of California Press.

https://doi.org/10.1525/california/9780520294240.001.0001

Hess, S. (2009). Person and place. New York and Oxford: Berghahn.

Hilliard, D. (1978). God's gentlemen. St.Lucia: University of Queensland Press.

Jolly, M. (1994). Women of the place. Churc: Harwood Academic Publishers.

Kolshus, T. (2010). Farskapningen - betraktninger over makten i et barnesete. Nytt Norsk Tidsskrift 27, 401-410. 
Kolshus, T. (2011). Relativisme, intervensjonisme og aktivisme: Robert Henry Codrington og den anglikanske Melanesian Mission i imperialismens tidsalder. DIN Tidsskrift for religion og kultur 16, 95-120.

Kolshus, T. (2013). Codrington, Keesing, and Central Melanesian mana: Two historic trajectories of Polynesian cultural dissemination. Oceania 83, 316-327. https://doi.org/10.1002/ocea.5027

Kolshus, T. (2014). A House upon Pacific sand. W.H.R. Rivers and his 1908 ethnographic "survey work". I C. Berg and E. Hviding (red.) The ethnographic experiment: Rivers and Hocart in Melanesia 1908 (s 155-176). New York og Oxford: Berghahn.

Kolshus, T. (2016a). Mana on the move: Why empirical anchorage trumps theoretical drift. I M. Tomlinson og T. Tengan (red.) New mana. Transformations of a classic concept in Pacific languages and cultures (s. 155-182). Canberra: Australian National University Press.

Kolshus, T. (2016b). Review of 'Global Pentecostalism in the $21^{\text {st }}$ century'. American Ethnologist 43, 769-770. https://doi.org/10.1111/amet.12401

Kolshus, T. (2017). Urban castaways. The precarious living of marooned islanders. I H. Lee og J. Taylor (red.) Mobilities of Return. Pacific Perspectives (s. 171-188). Canberra: Australian National University Press.

Kolshus, T. og E. Hovdhaugen (2010). Reassessing the death of bishop John Coleridge Patteson. Journal of Pacific History 45, 331-355. https://doi.org/10.1080/00223344.2010.530813

Lévi-Strauss, C. (1964). Totemism. London: Merlin Press.

Lévi-Strauss, C. (2002). Den ville tanke. Oslo: Spartacus.

Malinowski, B. (1922). Argonauts of the western Pacific. London: Routledge \& Kegan Paul. Marx, K. og F. Engels (1974). Den tyske ideologi. København: Forlaget Rhodos.

Marx, K. (n.d.). A contribution to Hegel's philosophy of right. Tilgjengelig på https://www.marxists.org/archive/marx/works/1843/critique-hpr/intro.htm, lest 23. januar 2019.

Niebuhr, R. (1929). The social sources of denominationalism. New York: Holt.

Norman, K. (2018). Sweden's dark soul. London: Hurst Publishers.

Nongbri, B. (2013). Before religion: A history of a modern concept. New Haven, CT: Yale University Press.

https://doi.org/10.12987/yale/9780300154160.001.0001

Rappaport, R. A. (1968). Pigs for the Ancestors. New Haven: Yale University Press.

Rio, K. M. (2007). The Power of Perspective: Social Ontology and Agency on Ambrym Island, Vanuatu. Oxford: Berghahn Books.

Rivers, W. H. (1914). The history of Melanesian society. Cambridge: Cambridge University Press.

Robbins, J. (2007). Continuity thinking and the problem of Christian culture. Current anthropology 48 (1), 5-38. https://doi.org/10.1086/508690

Scott. M. W. (2013). 'Heaven on earth' or Satan's 'base' in the Pacific. I M. Tomlinson og D. McDougall (red) Christian politics in Oceania (s. 49-77). New York og Oxford: Berghahn.

Tambiah, S. (1989). Ethnic conflict in the world today. American Ethnologist 16, 335-349. https://doi.org/10.1525/ae.1989.16.2.02a00090

Thurston, W. R. (1987). Processes of change in the languages of North-Western New Britain. Canberra: The Australian National University.

Tomlinson, M. og D. McDougall (red.) (2013). Christian politics in Oceania. New York og Oxford: Berghahn. 
Tuzin, D. (1997). Cassowary's revenge. Chicago: The University of Chicago Press. Weber, M. (2005). Den protestantiske etikk og kapitalismens ånd. Oslo: Bokklubben.

' Tidligere versjoner av denne artikkelen ble presentert på årsmøtet i Norsk Gammeltestamentlig Selskap og for forskergruppen Mangfoldsstudier i profesjon og samfunn ved OsloMet. Jeg er takknemlig for både invitasjoner og verdifulle kommentarer. En stor takk går også til Tom Bratrud, for mange konstruktive og treffsikre innspill til den endelige versjonen av artikkelen. De tilkortkommenheter som har overlevd hans grundige lesning, skal kun tilskrives forfatterens stahet.

ii For en interessant analyse av moderniteten som styrende narrativ for europeisk selvforståelse, se Vassos Argyrou 2003. I den moderne klassikeren Time and the Other (1983) plasseres Johannes Fabian denne tenkningen i en bred idehistorisk og metaantropologisk sammenheng.

iii Webers berømte historiske analyse av kapitalismens fremvekst i Europa (2005) tar utgangspunkt i forskjellene mellom romersk-katolsk og protestantisk gudsbilde, etikk og personforståelse. Marx tillegges ofte et ensidig negativt syn på religion som et politisk redskap kontrollert av elitene, uforlignelig oppsummert med soundbiten om hvordan de herskendes tanker blir de herskende tanker (Marx og Engels, 1974: 58-59). Men det er sjelden å se hans hyppigst siterte religionskarakteristikk gjengitt i sin mer nyanserike kontekst, som lyder: «Religion er den kuede skapnings sukk, en hjerteløs verdens hjerte og sjelløse tilstanders sjel. Den er opium for folket.»

https://www.marxists.org/archive/marx/works/1843/critique-hpr/intro.htm, lest 29. januar 2019, min oversettelse.» iv Hans hovedverk fra 1912, The elementary forms of religious life (1995) er usedvanlig rikt og metodologisk nyansert, der han også med velutviklet kritisk sans gjennomgår tidligere teoretikeres tilnærminger til religion. I et essay jeg skrev om den norske velferdsstatens eskatologiske undertoner (Kolshus, 2010), viste Durkheim seg å være svært nyttig.

$\checkmark$ Den toneangivende blant disse var James George Frazer, som med sitt tolvbinds verk The golden bough (1996) søkte å forklare utviklingen fra magisk via religiøs til vitenskapelig tenkning.»

vi Jeg har to lengre feltarbeid, 1996-97 og 2002-03, i tillegg til to kortere felttur i 2012 og 2016, på til sammen 25 måneder. I tillegg har jeg utført omfattende studier i de rike arkivene som er tilknyttet den anglikanske Melanesian Mission og den selvstendige Anglican Church of Melanesia.

vii For en introduksjon til den anglikanske Melanesian Missions missiologiske strategier og kulturrelativisme, se for eksempel Kolshus 2011, 2013 og 2014.

viii I sin monografi Person and place (2009) beskriver Sabine Hess tilstanden i en landsby der anglikanere og SDA-folk har levd parallelle liv i tredve år, på tross av at samtlige er i slekt med hverandre. Michael W. Scott (2013) beskriver det samme fra Salomon-øyene. For et tilfelle som ikke omhandler SDA, se Donald Tuzin (1997).»

ix Hans hovedverk, The Melanesians (1891) var av en slik kvalitet at det ble referert til i nær samtlige teoretiske debatter i sosialantropologi til langt inn på 1960-tallet. For en vurdering av hans varige bidrag, se for eksempel Kolshus 2011 og 2014.»

× At Mota også var et arnested for sentrale bidrag i antropologiens tidlige historie, var på noen få personer nær av begrenset interesse - selv om de fleste fant det helt naturlig at jeg hadde reist så langt for å studere deres liv og levnet, ettersom dansene tilknyttet de hemmelige Tamate- mannskultene var kjent som de flotteste i Vanuatu.

xi Det var delvis kirkepolitiske årsaker som gjorde at Melanesian Mission gled over fra sin opprinnelige høykirkelige anglikanisme til å bli eksplisitt anglokatolsk rundt 1920. Men først og fremst var dette en misjonsstrategisk avgjørelse, foretatt av en ny generasjon misjonærer som pleiet mindre omgang med melanesiere og derfor hadde begrenset tiltro til deres intellektuelle kapasitet. Det er ingen tilfeldighet at argumentasjonen lignet på den som ble brukt til å begrunne hvorfor anglikanske kirker i arbeiderklassestrøk var langt mer fokusert på ritualer og det sanselige og mindre prekenorientert (se for eksempel Hilliard, 1978: 233). I Melanesian Missions tidsskrift oppgav den innflytelsesrike misjonæren (og talentfulle etnografen) Walter Durrad følgende begrunnelse for valget: «The staid and sober services of half a century ago [...] seem to make no appeal to these emotional people, who are like Southern Europeans in love of colour and dramatic element. We need to get rid of the drab from the picture and give some appeal to the imagination and the eye. These people are children. With them laughter and tears are close together, and they are as easily moved to the one as to the other. The cold, solemn, calculating, serious, reasoning, AngloSaxon is surprised at such emotionalism and apparent inconsistency, but it is certain that we must strive to take account of the native viewpoint if we are ever to influence the people as a whole.» (Durrad, 1912: 343).

${ }^{x i}$ Anglican Church of Melanesia har i de senere år innført en skala fra mindre viktige (klasse 3), viktige (klasse 2) og svært viktige (klasse 1) hellige menn og kvinner, for å ta hensyn til spesielt foreldres behov for å dyrke salgbare hageprodukter som kan dekke skolepenger for barna. Klasse 3 omfatter cirka halvparten av dagene, og regelen er at hvis du gikk til høymesse har du lov til å jobbe etterpå. Hvis du ikke var til stede i kirken, må du også vente med å jobbe til ettermiddagen. 